\title{
ANTI-MICROBIAL ACTIVITY OF SILVER NANO PARTICLES (AG-NPS) ON BACTERIA ISOLATED FROM DIABETIC FEET
}

\author{
By \\ Safia Ahmed Amin*, Mohamed E. A. Dawood*, Mohamed Mahmoud**, \\ and Doaa Gheeth***

\begin{abstract}
*Botany and Microbiology Department, Faculty of Science, Cairo University, **Biophysics Department, Faculty of Science, Cairo University, ***Clinical Pathology Department, Faculty of Medicine, Cairo University
\end{abstract} \\ E-Mail: mohamedeisa89@yahoo.com
}

\begin{abstract}
Background: Silver nanoparticles (Ag NPS) have long been known to have powerful antimicrobial activities.

The aim of this study: to synthesize of silver nanoparticles (Ag NPS) in chitosan composite for possible use in biological application.

Objective: Chitosan - silver nanoparticles composite materials was synthesized by adding AgNo3 0.5 gm and $\mathrm{NaOH}$ solution to chitosan solution at $120 \mathrm{c}$. Different concentrations of chitosan $0.05 \%-0.125 \%-$ $0.25 \%-0.5 \%$ were used for synthesis. Chitosan - silver nanoparticle composite materials were characterized by Ultraviolet visible spectroscopy (UV), particles size and zeta potential (NCS) and transmission electron microscopy (TEM). Bacteria isolated from diabetic feet were used to test the bactericidal efficiency of synthesized chitosan - silver nanoparticles composite materials. Results: The bacteriological tests showed either bacterial growth inhibition or cell death occurred depending on the concentration of chitosan used. Antibacterial effect of chitosan - silver nanoparticles composite materials increased by increasing chitosan concentration.
\end{abstract}

Conclusion: The presence of Ag- nanoparticles in different concentrations of chitosan composite was enough to significantly enhance antibacterial activity.

Key words: silver nanoparticles (Ag NPS), Characterization, Diabetic feet, Antimicrobial Activity.

\section{INTRODUCTION}

Nanotechnology means any technology on a Nano scale that has applications in the world, nanotechnology has many applications in physical, chemical, and biological systems at scales ranging from individual atoms or molecules to submicron dimensions, nanotechnology have impact on our economy and society in the early $21^{\text {st }}$ century. Science and technology research in Nanotechnology promise breakthrough in areas as manufacturing, medicine, Nano electronics and healthcare, its widely felt that Nanotechnology will be the next industrial revolution. The definition of nanoparticles is an aggregate of atoms bonded together with radius between 1 and $100 \mathrm{~nm}$. The discovery of novel materials, processes and phenomena at 
Nano scale and development of new experiment and theoretical technique for research provide new opportunities for development of Nano system and nanostructured materials (Bhui et al., 2011). Chitosan obtained from a natural polymer chitin has antibacterial feature. As a polycationic polymer, chitosan is an environmentally friendly material because of its biodegradability. Nontoxic and antibacterial features of chitosan make it usable for many areas related to human health (Zhang et al., 2012). Silver (Ag) ion has been used for a long time as antibacterial agent due to its strong inhibiting effect on bacteria. Recently, nanoparticle $\mathrm{Ag}$ has taken considerable attention to provide maximum bactericidal effect with minimum amount of $\mathrm{Ag}$ (CaO et al., 2010). Comparative studies showed that chitosan-Ag nanoparticle composite is much more effective against bacteria than pure chitosan (Ali et al., 2011). Chitosan is also used as a stabilizer instead of chemical reducing agent for protecting $\mathrm{Ag}$ nanoparticles from agglomeration. Because of these specialties of chitosan and Ag, chitosan-Ag nanoparticle composite has been taken in attention (Tankhiwale et al., 2010 and Ali et al., 2011). In these studies, characterization of chitosan-Ag nanoparticles by spectroscopic methods and antibacterial effects of these materials was investigated. However, chitosan (Zhang et al., 2012).Ag nanoparticle separately have been studied extensively (Spadaro et al., 2012) but further investigations about chitosan-Ag nanoparticles are only rarely carried out. Different techniques were preferred to synthesize chitosan-Ag nanoparticle composites by researchers (Tankhiwale et al., 2010 and Ali et al.,
2011). The chitosan- Ag nanoparticles were prepared using chitosan in aqueous solution of acetic acid ( $\mathrm{Li}$ et al., 2013). Transmission electron microscopy (TEM), UV spectrophotometer and particles size and zeta potential (NCS) were used for characterization of the size and structure of chitosan-Ag nanoparticles (Ali et al., 2011). The antibacterial effectiveness was determined by bacteria isolated from diabetic feet. In this study, chitosan-Ag nanoparticle composite was synthesized by biological method in the aqueous sodium hydroxide (Nadagouda et al., 2011). Both of the structural characterization and antibacterial effectiveness of chitosan-Ag nanoparticles against bacteria isolated from diabetic feet were investigated. The effect of chitosan concentration of the composite material on the structure and antibacterial activity was also investigated.

\section{MATERIALS AND METHODS}

This study has been performed in Biophysics Department, Faculty of science, Cairo University and Clinical Pathology Department, Cairo University Hospital, Egypt.

a. Chemicals: Silver nitrate (Ag NO3), chitosan, acetic acid and sodium hydroxyl $(\mathrm{NaOH})$, most these chemicals were purchased from sigma chemicals CO ADWTC Egypt.

The used water was distilled by using water distillation apparatus.

b. Different types of media: Different types of media can be used depending on type of microorganism we wish to isolate.

- Selective media contained substances that stimulates the growth of all 


\section{ANTI-MICROBIAL ACTIVITY OF SILVER NANO PARTICLES (AG-NPS)...}

bacteria and suppresses the growth of unwanted bacteria (e.g. Tetrathionate broth that inhibits coliforms).

- Differential Media allowed only a particular type of bacteria to grow on it, (e.g. MacConkey agar for growing gram-negative bacteria).

- Anerobic Media was used for growing anaerobic organisms (e.g. Roberson's cooked meat).

- Blood Agar Media are enriched, differential media used to isolate fastidious organisms and detect hemolytic activity. $\beta$ - Hemolytic activity showed lysis and complete digestion of red blood cell contents surrounding colony.

Chitosan solution $0.5 \%$ was prepared by dissolving $0.5 \mathrm{gm}$ chitosan in acetic acid $(100 \mathrm{ml} / 0.1 \%)$. Silver nitrate 0.5 $\mathrm{gm}$ was added to $10 \mathrm{ml}$ of deionized water, and then mixed with $50 \mathrm{ml}$ of chitosan solution on heating with magnetic stirring at 120 C. $1.5 \mathrm{ml} \mathrm{NaOH}$ was added drop by drop, and the mixture was heating for approximately $20 \mathrm{~min}$. Yellow color appeared after adding $\mathrm{NaOH}$, indicating the formation of chitosan-silver nanoparticles. The study varying concentration of chitosan $0.5 \%$ $0.25 \%-0.125 \%-0.05 \%$ were used.
The preliminary detection of silver nanoparticles was carried out by visual observation of color change of mixture (yellow color appeared). UV-Visible spectroscopy was used to track silver nanoparticles. Formation in chitosan mixture absorption measurement were carried out on (UV-3/0.1 pc UV - vis NIR scanning spectrophotometer) and scanning the spectra between $350 \mathrm{nM}$ and $700 \mathrm{Nm}$ at resolution of $1 \mathrm{Nm}$. Particle size and zeta potential were assessed on zeta sizer Nano Zsgo by dynamic light scattering measurement (DLS) the analysis was performed at scattering angle of $90 \mathrm{o}$ under 25 C. (TEM) Transmission were done by using a (JEol -2100 high resolution TEM) operated at an accelerating voltage at 200 KV. The histogram of particle size distribution was constructed analyzing several frames of similar images.

Medical specimens were collected from infector wounds of (25) diabetic feet's patients at El -Kasur EL -Eine hospital in Egypt.

Isolates were cultured by using aerobic and anaerobic microbiology techniques, and identified by morphological, staining methods, and biochemical tests. Isolates were also tested for susceptibility to commonly used antibiotics and different concentration of Ct-Ag NPs. 


\section{RESULTS}

Readed UV-visible absorption spectra was quite sensitive to formation of silver nanoparticles because of the fact that silver nanoparticle exhibit an intensive absorption peak due to surface plasmon resonance (SPR). Figures (1-2-3-4) showed the UV-visible spectra of silver nanoparticles prepared with different concentration of chitosan. All spectra exhibitied an absorption band in range of (385nm - 425nm) atypical plasmon resonance band of silver nanoparticles. A single strong peak with maximum around $425 \mathrm{~nm}$ was observed in UV-visible spectroscopies, which correspond to typical (SPR) of conducting electron from surface AgNPs.

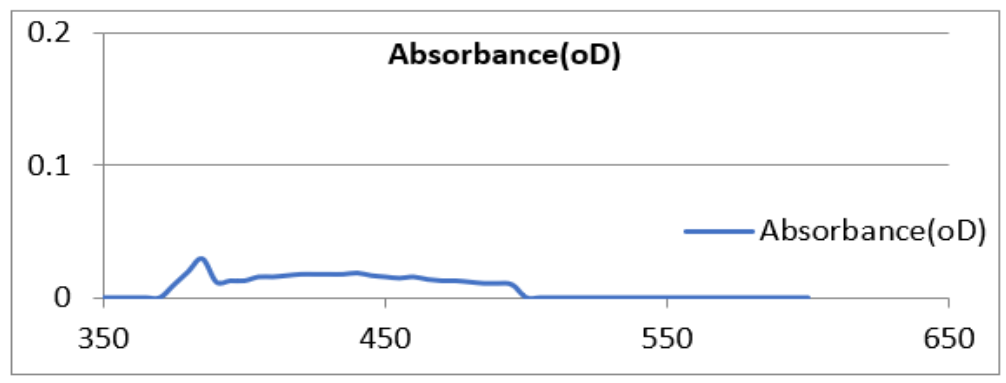

Figure (1): UV-visible absorption of ch-silver nanoparticle $(0.05 \%)$ of chitosan

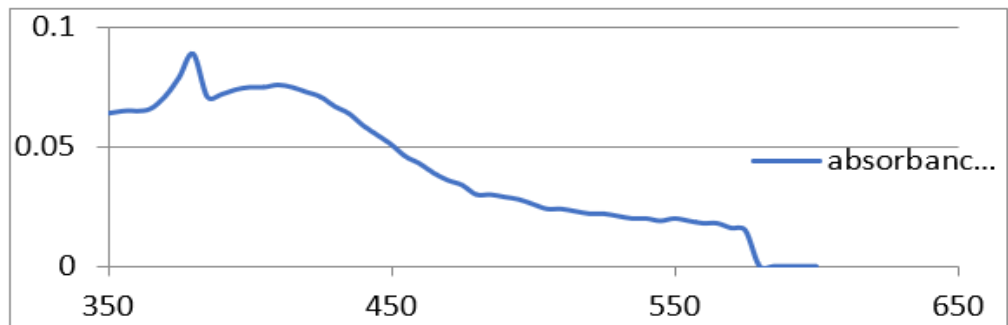

Figure (2): UV-visible absorption of ch- silver nanoparticle $(0.125 \%)$ of chitosan

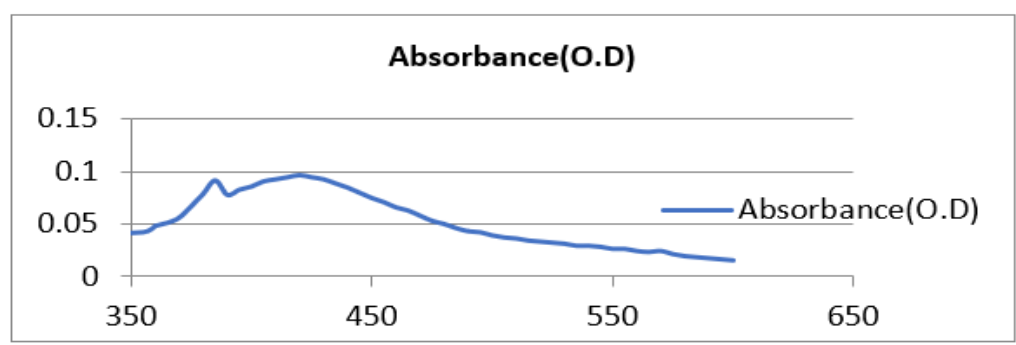

Figure (3): UV-visible absorption of ch- silver nanoparticle $(0.25 \%)$ of chitosan

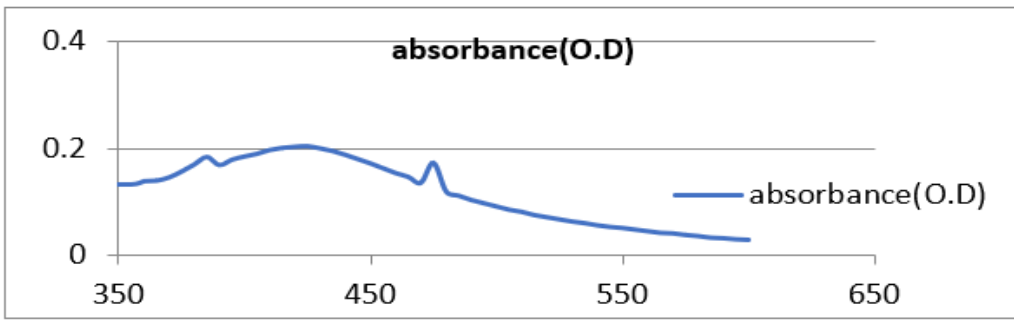

Figure (4): UV-visible absorption of ch- silver nanoparticle (0.5\%) of chitosan 


\section{ANTI-MICROBIAL ACTIVITY OF SILVER NANO PARTICLES (AG-NPS)...}

The zeta value measured for 4 concentrations of ct-AgNps Chitosan $(0.05 \%-0.125 \%-0.25 \%-0.5 \%)$. Zeta

potential showed that ct-AgNps are (positive charge). the surface net charge was around (32.6 - 45.2) mv (Table 1).

Table (1): Zeta potential of chitosan -silver nanocomposite

\begin{tabular}{|c|c|c|c|c|}
\hline \multicolumn{5}{|c|}{ Zeta potential analysis } \\
\hline & Ct $0.05 \%$ & Ct $0.125 \%$ & Ct $0.25 \%$ & Ct $0.5 \%$ \\
\hline Zeta potential (mv) & 32.6 & 37.5 & 42.6 & 45.2 \\
\hline Zeta deviation(mv) & 11.5 & 11.8 & 11.0 & 9.65 \\
\hline Conductivity (ms/cm) & 8.10 & 6.68 & 7.0 & 7.87 \\
\hline Polarity & Positive & Positive & positive & positive \\
\hline Pdi (poly dispersity index) & 0.345 & 0.367 & 0.293 & 0.203 \\
\hline \multicolumn{5}{|c|}{ Sample information } \\
\hline \multicolumn{5}{|c|}{ Fluid } \\
\hline Viscosity & \multicolumn{4}{|c|}{0.8872} \\
\hline Temperature & \multicolumn{4}{|c|}{25} \\
\hline Di electric const & \multicolumn{4}{|c|}{78.5} \\
\hline \multicolumn{5}{|c|}{ Dispersant } \\
\hline $\mathrm{Ph}$ & \multicolumn{3}{|c|}{ p } & \\
\hline \multicolumn{5}{|c|}{ Particle } \\
\hline Concentration & \multicolumn{3}{|c|}{0} & \\
\hline
\end{tabular}

The zeta value measured for charge and size distibution of ct-AgNps $0.05 \%$. positive charge; the surface net charge zeta potential showed that ct-AgNps are was around $32.6 \mathrm{mv}$ (Fig .5).

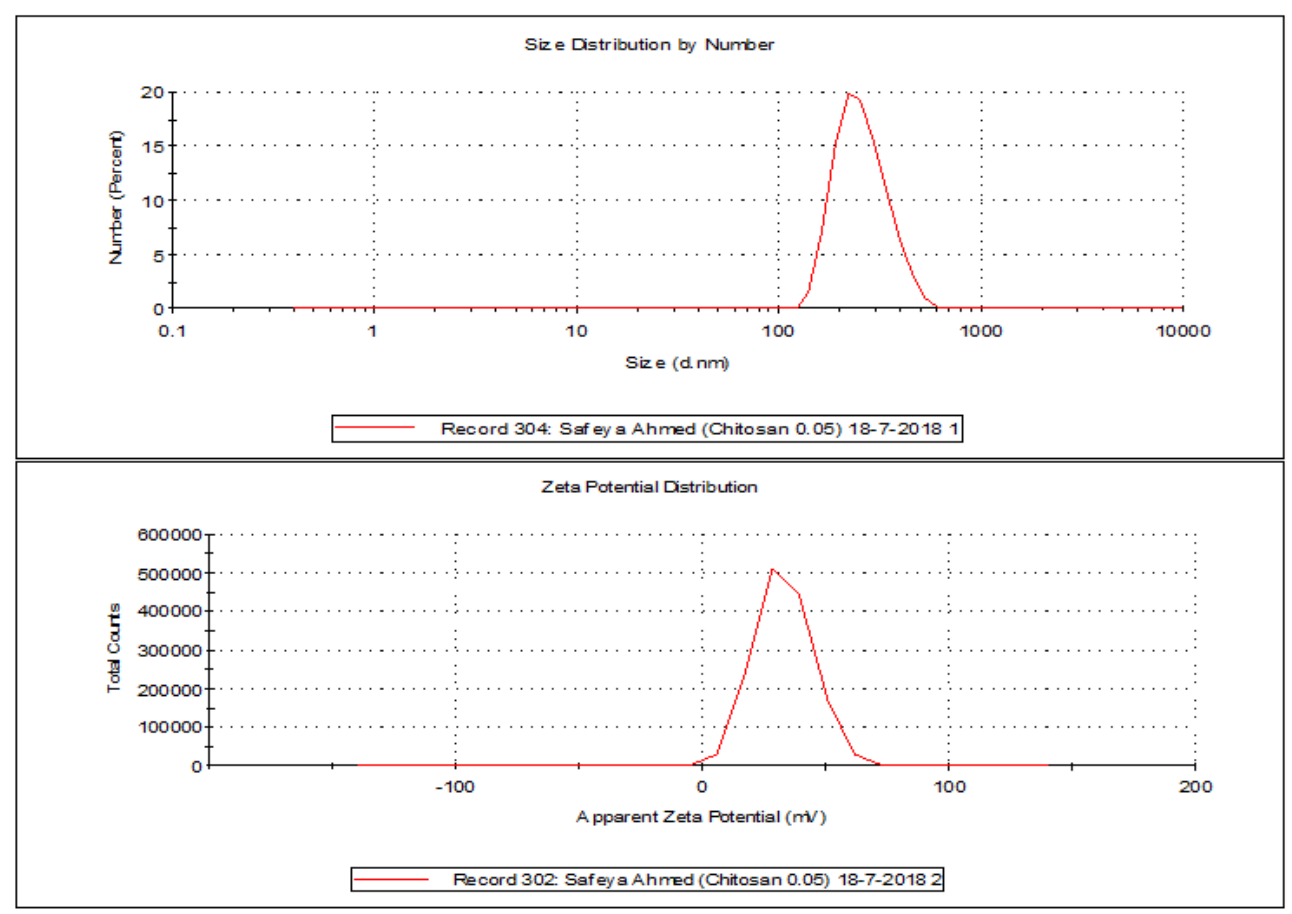

Fig(5): Zeta potential distribution (charge and size distibution) of chitosan( $(0.05 \%)$ 
The zeta value measured for charge and size distibution of ct-AgNps $0.125 \%$. positive charge. The surface net charge Zeta potential showed that ct-AgNps are was around $37.5 \mathrm{mv}$ (Fig .6).

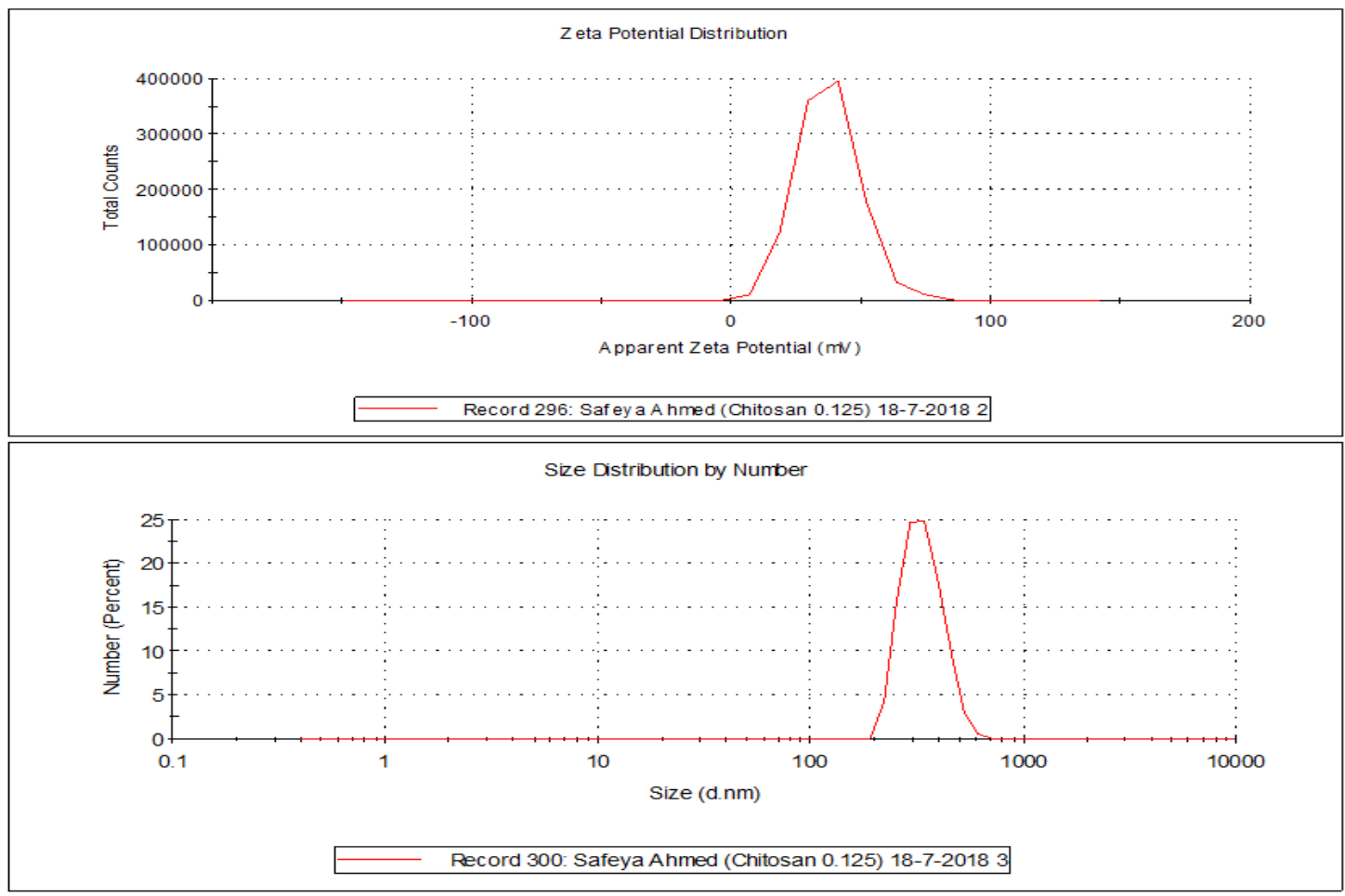

Fig(6): Zeta potential distribution (charge and size distribution) of chitosan(0.125\%)

The zeta value measured for charge positive charge. The surface net charge and size distibution of ct-AgNps $0.25 \%$. was around $42.6 \mathrm{mv}$ (Fig .7).

Zeta potential showed that ct-AgNps are

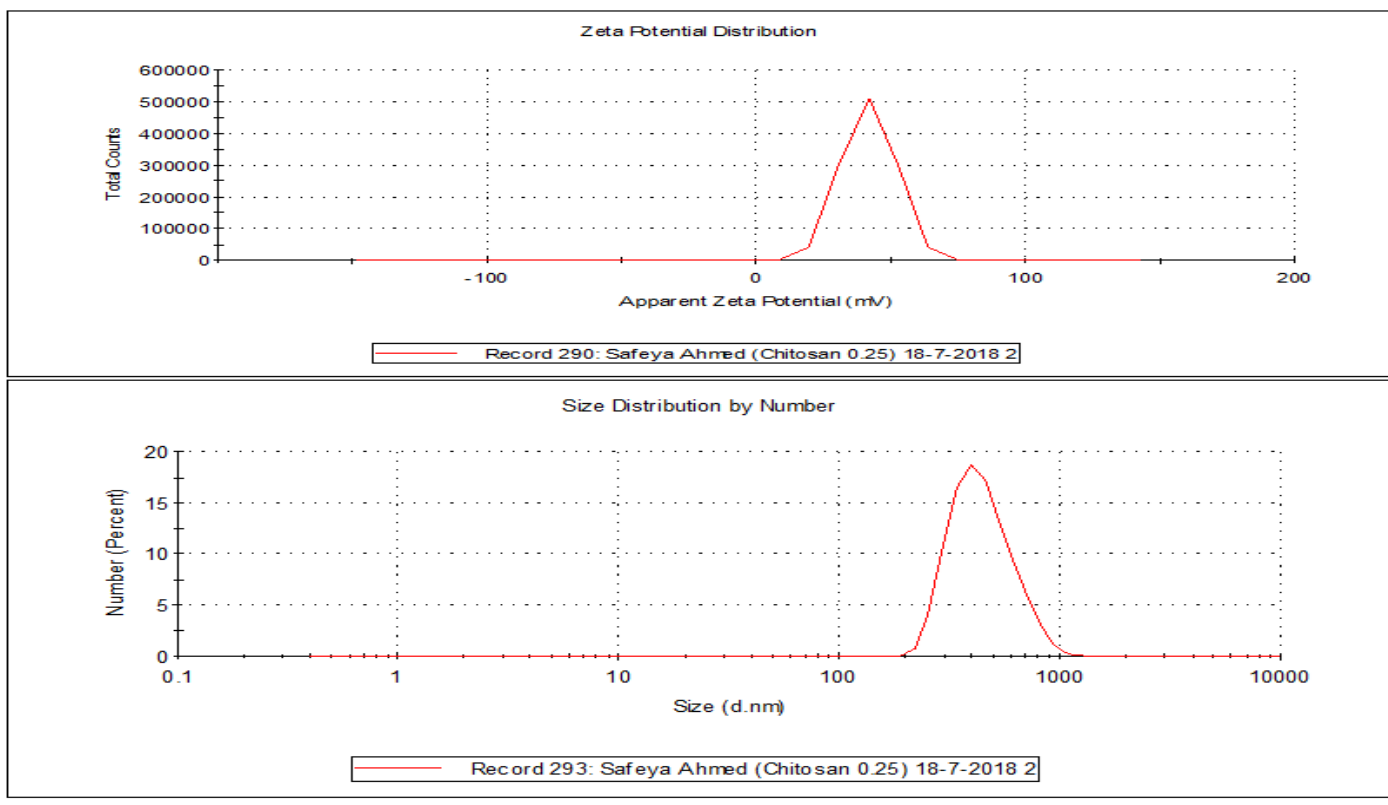

Fig (7): Zeta potential distribution (charge and size distibution) of chitosan $(0.25 \%)$. 


\section{ANTI-MICROBIAL ACTIVITY OF SILVER NANO PARTICLES (AG-NPS)... ${ }^{429}$}

The zeta value measured for charge and size distibution of ct-AgNps $0.5 \%$. Zeta potential showed that ct-AgNps are positive charge. The surface net charge was around $45.2 \mathrm{mv}$ (Fig .8).

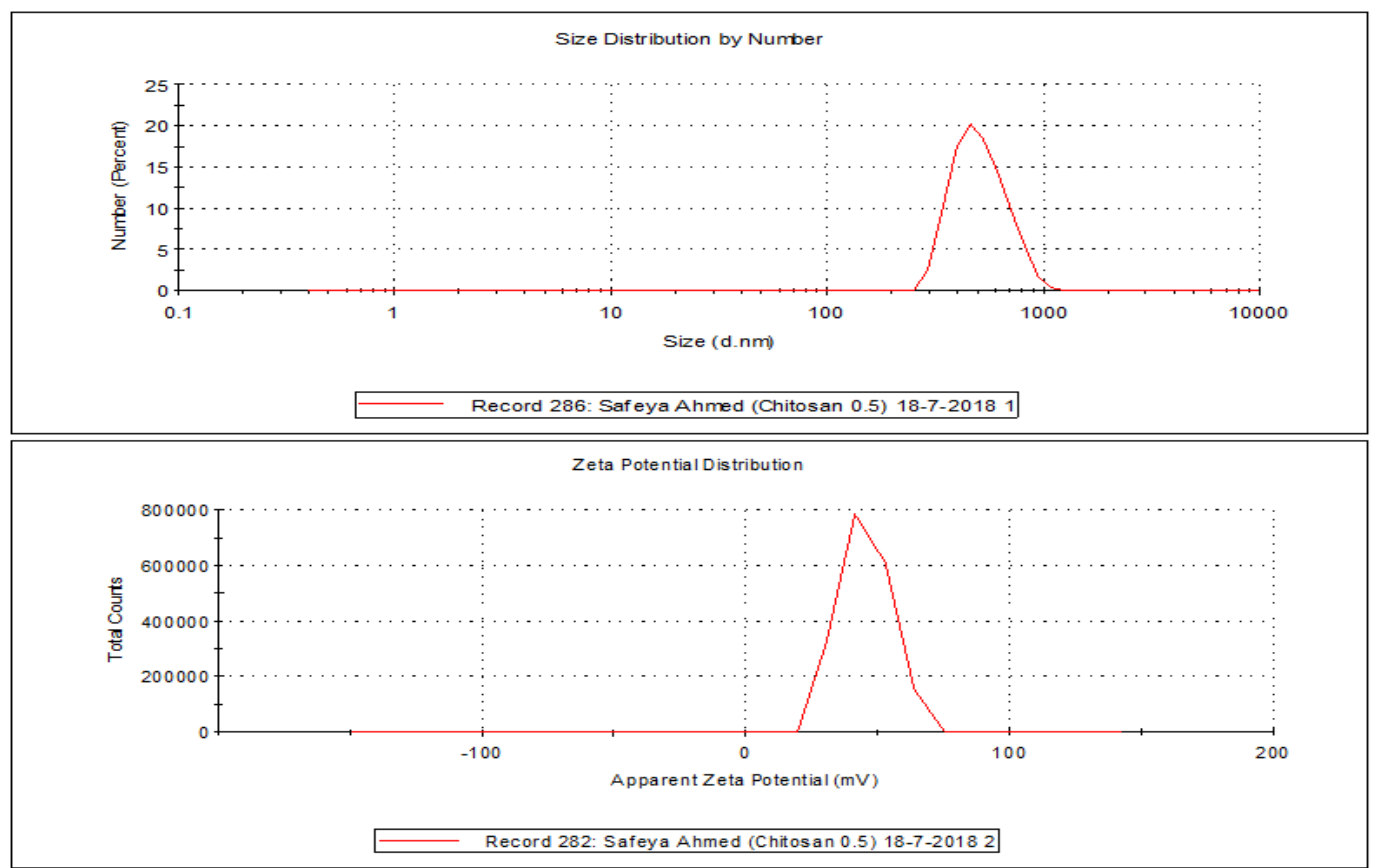

Fig (8): Zeta potential distribution (charge and size distribution) of chitosan (0.5\%)

TEM provide vertical direction information by acquisition of electrons projected through the entire film TEM image of AgNps conjugated with different concentration of chitosan polymer $(0.05 \%$ - $0.125 \%-0.25 \%$ - $0.5 \%)$. TEM photograph of chitosan $-\mathrm{Ag}$ nanoparticles

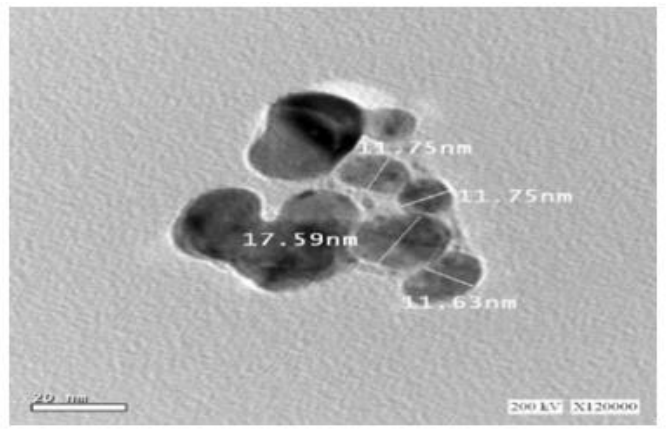

Photo(1):HRTEM of ch- AgNps (0.05\%). were achieved to be nano size and $\mathrm{Ag}$ particles were well dispersed in chitosan matrix with average diameter of around $(0.03-20) \mathrm{nm}$. The particles were spherical and homogenous and dispersed in chitosan polymer (Photos 1,2,3\&4).

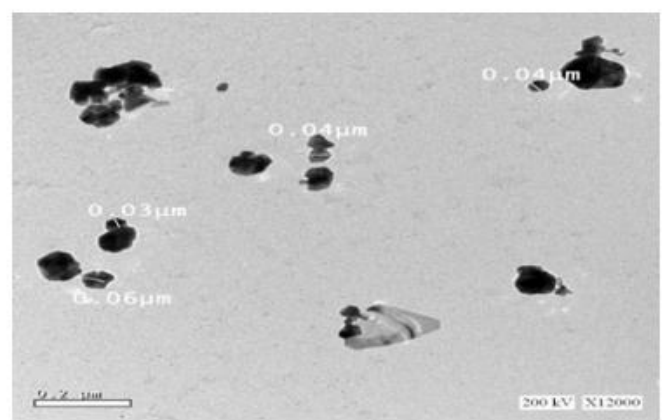

Photo (2): HRTEM of ch- AgNps (0.125\%). 


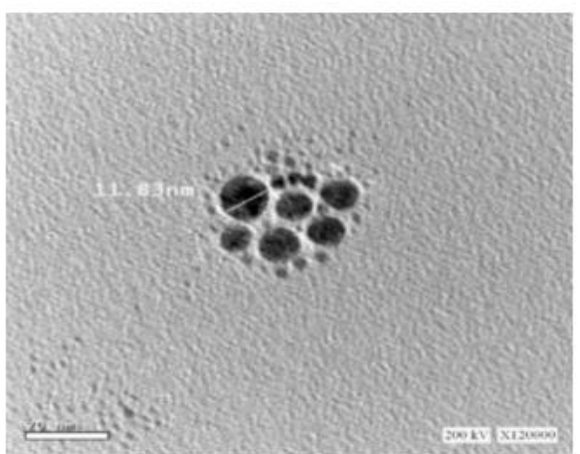

Photo ( 3 ):HRTEM Photo of ch- AgNps (0.25 \%)

Identification of bacteria by biochemical tests was isolated from

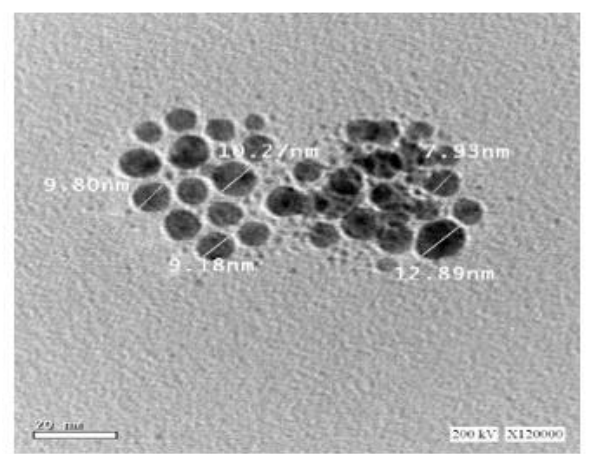

Photo ( 4 ): HRTEM Photo of ch- AgNps (0.5\%).

patient with different age and different diabetic duration range (Table 2).

Table (2): Identification of bacteria by biochemical tests

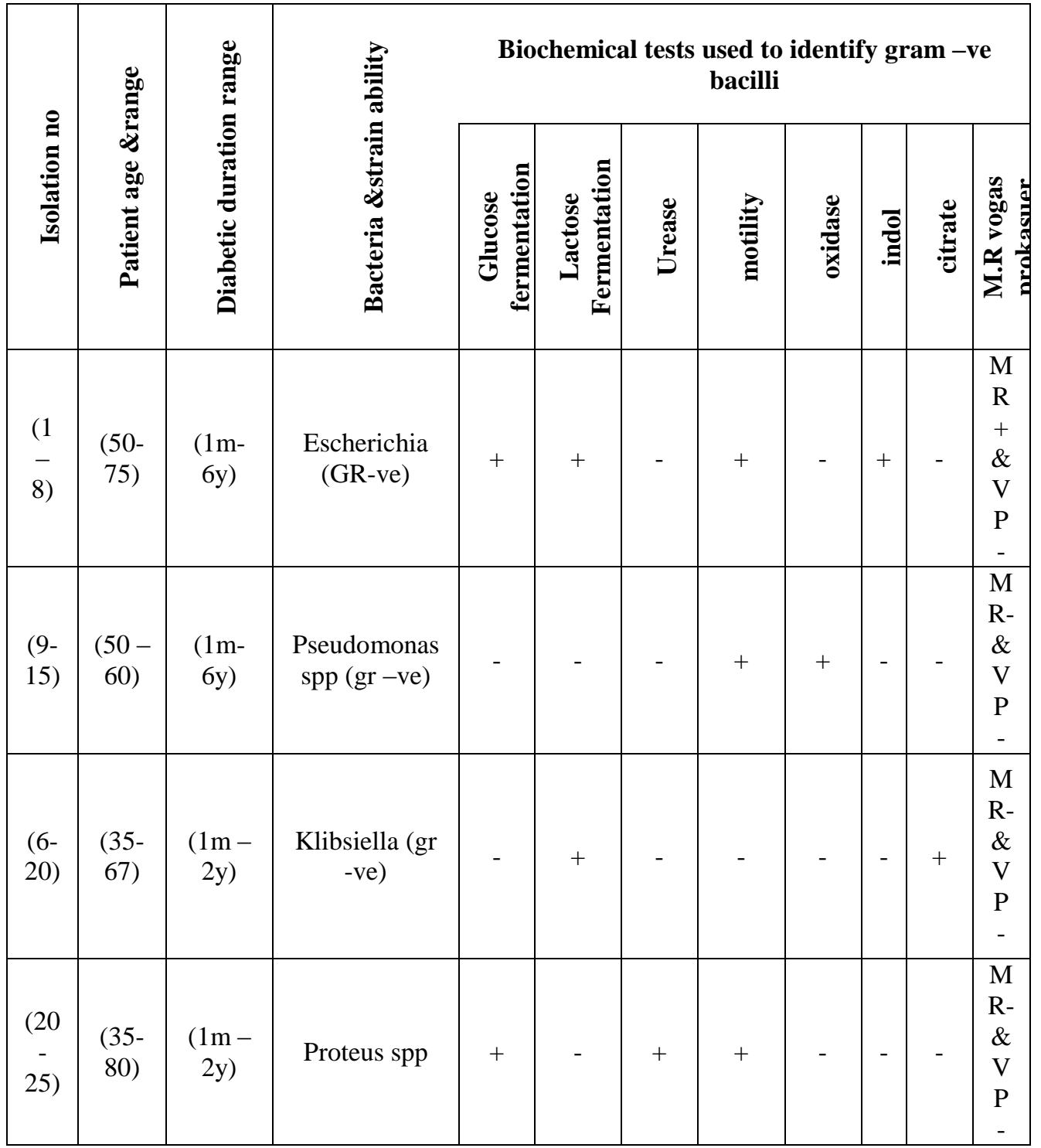




\section{ANTI-MICROBIAL ACTIVITY OF SILVER NANO PARTICLES (AG-NPS)...}

The Most common type of bacteria isolated from diabetic feet is E-coli which

represented $(32 \%)$ of total number of isolates (Table 3).

Table(3): precent of types bacteria in diabetic feet.

\begin{tabular}{|c|c|c|c|}
\hline Total number & Present (positive) & Abcent (Negative) & Precent (\%) \\
\hline Escherichia coli & 8 & 19 & $32 \%$ \\
\hline Pseudomonas spp & 6 & 22 & $24 \%$ \\
\hline Klebsilla spp & 5 & 20 & $20 \%$ \\
\hline Proteus spp & 6 & 24 & $24 \%$ \\
\hline
\end{tabular}

Concentration of CT-AgNPs $0.5 \%$ was the most effective and inhibitor concentration, but CT-AgNPs $0.05 \%$ and
$0.125 \%$ have no any effect on bacterial isolate (Table 4).

Table (4): Effect of nanoparticles on response of bacteria

\begin{tabular}{|c|c|c|c|c|}
\hline $\begin{array}{l}\text { Eoncentration } \\
\text { Percentage. }\end{array}$ & Sensitive & Resistant & Intermediate & Total \\
\hline Chitosan $(0.05 \%)$ & 0 & 25 & 0 & 25 \\
\hline Chitosan $(0.125 \%)$ & 0 & 25 & 0 & 25 \\
\hline Chitosan $(0.25 \%)$ & 1 & 12 & 12 & 25 \\
\hline Chitosan $(0.5 \%)$ & 12 & 7 & 6 & 25 \\
\hline Total & $\mathbf{1 3}$ & $\mathbf{6 9}$ & $\mathbf{1 8}$ & $\mathbf{1 0 0}$ \\
\hline
\end{tabular}

\section{DISCUSSION}

In the current study AgNPs were synthesized in chitosan polymer by using biological methods the color was turned to yellow that indicated formation of ctAgNPs .This change in color has been previously observed by several investigator who suggested that the color change occurred due to the surface Plasmon resonance of deposited AgNPs and we observed that as concentration of ct- increase the color resultant turned to dark yellow. it could be seen that the absorption peaks at approximately (380 $425 \mathrm{~nm})$. Also, UV absorption peak of chitosan-Ag nanoparticles prepared by other researchers was recorded in the range 410-425 nm (Holtzet et al., 2012). The particle size distribution of ct-AgNps was analyzed by using (DLS) technique the graph of nanocomposite was found to be positively charged in contrast to earlier studies. TEM has provided the morphology and size details of AgNPs embedded in chitosan matrix.the particles embedded in crosslinking cts matrix are well separated and dispersed.The particles presented an elliptical spherical structure and their size no more than $(20 \mathrm{~nm})$. As no other protective agent added in the system, chitosan molecule acted as dispersant to prevent growth and aggregation of particle synthesis process of AgNPs and this result similar to Benn (2010).

Furuo et al. (2014) reported that AgNps were known to have strong antimicrobial activity towards Gram negative bacteria than gram positive and the results of identification of our 
experiment have showed that: total number of bacteria isolates was 25 which included 4 genera (Escherichia coli, pseudomonas spp, Klebsiella spp, and proteus spp). E.coli was the most common isolate, being from $32 \%$ of total number of bacteria and this results agreed with previous work carried out by Gadepilli et al. (2015) on 80 diabetic foots patients demonstrated that $82.5 \%$ of polymicrobial flora with an average of 2.3 species per patient and aerobic to anaerobic ratio was 5.5.The most commonly isolated pathogens were Staphylococcus aureus, proteus spp, and E.coli.

Another study by Zubair et al. (2012) reported that polymicrobial etiology in $65 \%$ cases of DFI with predominance of E. coli and S. aureus. In our experiment, we studied sensitivity of isolated bacteria to different concentrations of $\mathrm{Ct}-\mathrm{AgNps}$. The most effective concentration of $\mathrm{Ct}$ AgNps solution was $0.5 \%$. Helander et al. (2010) found that the presence of small percentage of AgNps in composite was enough to enhance antimicrobial activity scientifically towards Gram -negative and Gram-positive bacteria as compared with pure chitosan. In this study, we used AgNPS in different concentration of chitosan composite due to chitosan have been widely established as delivery matrices for number of pharmaceutical applications, and also to decrease release and toxicity of silver nanoparticles from composite.

\section{CONCLUSION}

The antibacterial properties of chitosan-Ag nanoparticle composite materials and the effects of chitosan concentration of composite materials on the structure and the antibacterial effectiveness were investigated against bacteria isolated from diabetic feet. Antibacterial effect of chitosan-Ag nanoparticle materials increased with increasing chitosan concentration of the composite material. The results of this study also suggested that the presence of a small percentage of $\mathrm{Ag}$ nanoparticles in different concentration of chitosan composite was enough to enhance antibacterial activity significantly towards isolated bacteria.

\section{REFERENCES}

1. Ali S, Rajendran $R$ and Joshi M. (2011): Synthesis and characterization of chitosan and silver loaded chitosan nanoparticles for bioactive polyester. Carbohydrate Polymers., 83(2): 438-446.

2. Benn, T.M. (2010): Nano particle silver released into water from commercially available sock fabrics Environ. Sci. Technol. 42, 4133-4139.

3. Bhui DK and Misra A. (2012): Synthesis of worm like silver nanoparticles in methyl cellulose polymeric matrix and its catalytic activity. Carbohydrate Polymer., 89:830-835.

4. Cao C, Cheng Y, Ma L and Zhao C. (2010): Preparation of silver nanoparticles with antimicrobial activities and the researches of their biocompatibilities," Journal of Materials Science., 21: 2861-2868.

5. Furno F.K., Morley B., Wong B.I., Sharp P.L., Arnold S.M., Hawdle R., Bayston D., Brown P.D and Winship H. (2004): Reid silver nanoparticles and Polymeric medical devices. Antimicrob. Chemother., 54: 10191024.

6. Gadepalli R., Dhawan B., Sreenivas V., Kapil S and Ammini A. (2006): Aclinico microbiological study of diabetic foot ulcers in: an Indian tertiary Care hospital. Diabetes care., 29:1727-32.

7. Helander I., Nurmiaho-Lassila E., Ahvenainen R., Rhoades $\mathbf{J}$ and Roller S. (2010): Chitosan disrupts the barrier 


\section{ANTI-MICROBIAL ACTIVITY OF SILVER NANO PARTICLES (AG-NPS)... 433}

properties of the outer membrane of Gramnegative bacteria. Food Microbiol., 71: 23544.

8. Holtez R., Lima B., Souza G., filho A., Brocchi $M$ and Alves, O. (2012): Nano Structured Silver Vanadate as a promising antibacterial additive to water-based paints. Nonotechnol. Biol. Med., 6: 935-940.

9. Li S., Lin M., Toprak M., Kim D and Muhammad M. (2013): Aqueous extract of Solanum nigrum inhibit growth of cervical carcinoma (U14) via modulating immune response of tumor bearing mice and inducing apoptosis of tumor cells. Fitoterapia., 79: 548556.

10. Nadagouda M., Speth $F$ and Varma $R$. (2011): Microwave-assisted green synthesis of silver nanostructures. Acc Chem Res., 44:469-478.

11. Spadaro D, Barletta E, Barreca F, Curro G and Neri F. (2010): Synthesis of PMA stabilized silver nanoparticles by chemical reduction process under a two-step UV irradiation. Appl Surf Sci., 256: 3812-3816.

12. Tankhiwale B and Bajpai S. (2010): Silvernanoparticle-loaded chitosan lactate films with fair antibacterial properties. Journal of Applied Polymer Science., 115 (3):18941900.

13. Zhang $X$, Geng H, Jiang $J$, Li J and Huang G. (2012): Synthesis and characteristics of chitin and chitosan with the (2-hydroxy- 3trimethylammonium) propyl functionality, and evaluation of their antioxidant activity in vitro, Carbohydrate Polymers., 89: 486-491.

14. Zubair M, Malik A and Ahmad J. (2012): Study of plasmid-mediated extended-spectrum beta- lactamase-producing strains of Enterobacteriaceae, isolated from diabetic foot infections in a North Indian tertiary-care hospital. Diabetes Technology \& Therapeutics, 14:315-324. 


\section{در اسة تأثثر جزيئات الفضة النانونية علي البكتريا المعزولة من القدم السكري}

صفية احمد امين ، محمد عز الدين داوود، محمد محمود- دعاء غيث

قسم النبات و الميكروبيولوجي، كليه العلوم، جامعة القاهرة

قسم الفيزياء الحيويه، كليه العلوم، جامعة القاهرة

قسم الباثولوجيا الاكلينيكيه، كلية الطب، جامعة القاهرة

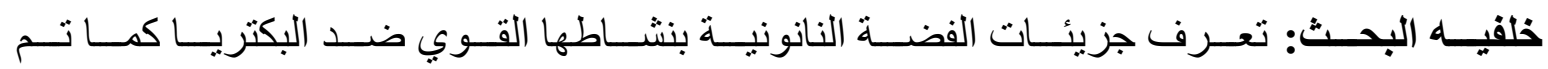

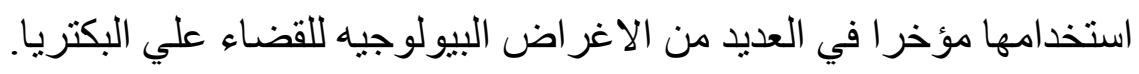

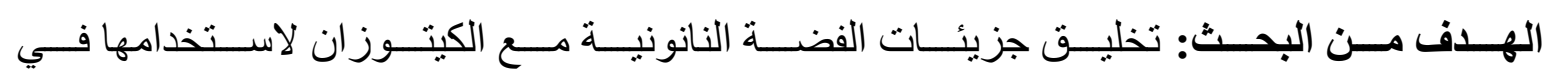
الأغر اض الحيوية.

طــرق ومــواد البحــث: تــم تصــنيع جزيئـات الفضـــة النانونيــة عــن طريـق اضـــافة نتـرات

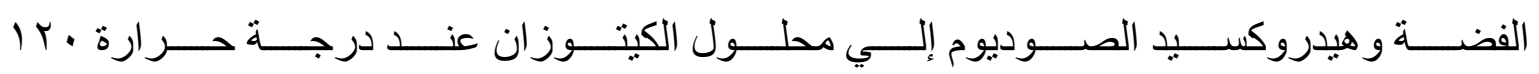

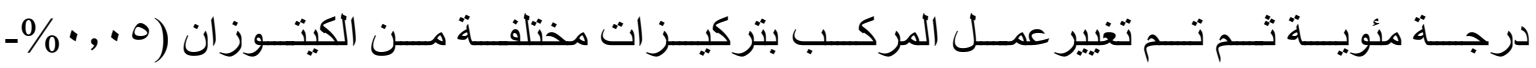

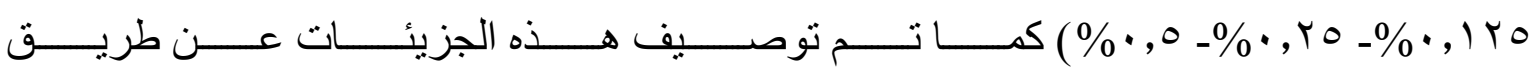

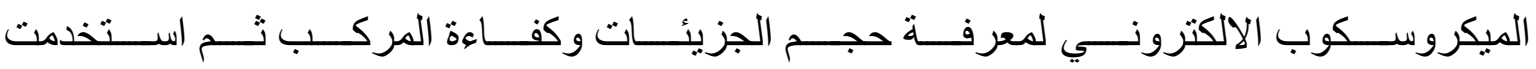

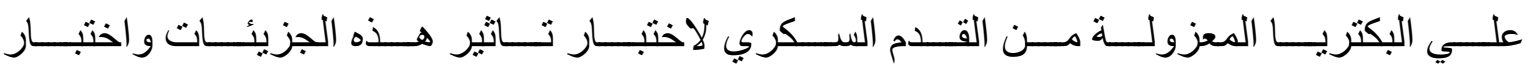
التركيزات المختلفة لجزيئات الفضة النانونية علي البكتيريا.

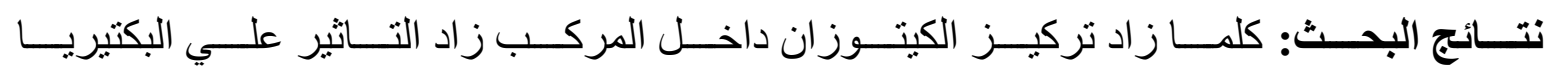

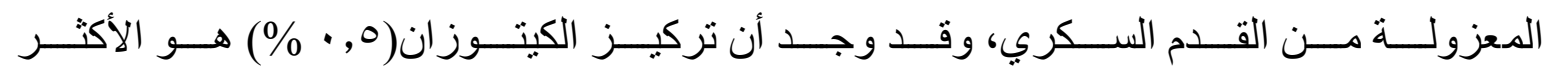

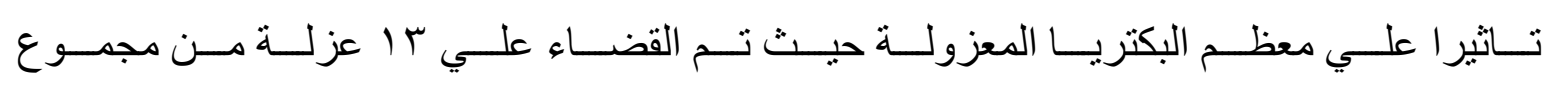
هr عزلة بينما التركيز الاول (0. . •\%) كانت البكتيريا مقاومة له.

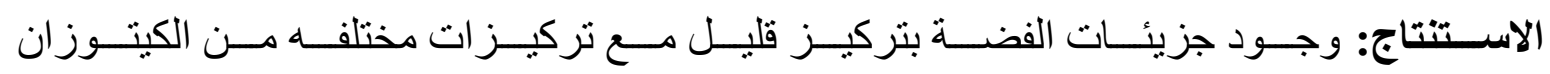
كافي لتثبيط نمو العديد من البكتريا المعزولة من القدم السكري. 
ANTI-MICROBIAL ACTIVITY OF SILVER NANO PARTICLES (AG-NPS)... 435

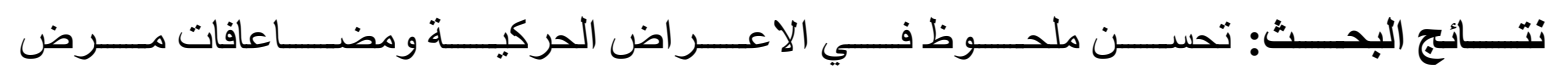

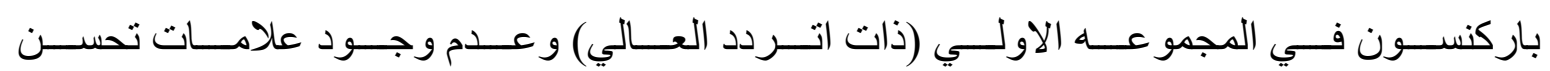
في المجمو عه الثانية (ذات التردد المنخفض) أو المجمو عة الحاكمة.

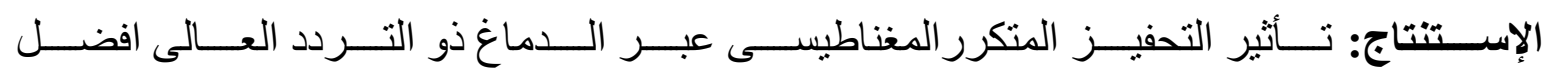

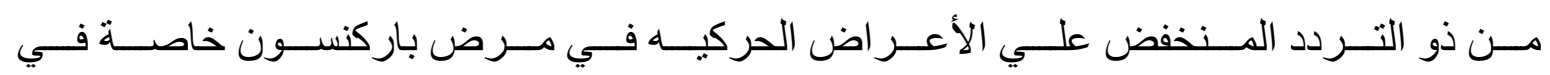
المر احل المتقدمة ذات المضاعفات. 